\title{
VAIHTELEVAA, AUTONOMISTA JA SISÄLLÖLTÄÄN TÄRKEÄÄ TYÖTÄ MÄÄRÄAIKAISISSA TYÖSUHTEISSA
}

\section{Katsaus kolmannen sektorin työoloihin}

\section{Kolmas sektori myllerryksessä}

Kolmannen sektorin merkitys työllistäjänä on kasvanut viimeisten 20 vuoden aikana. Työja elinkeinoministeriön (TEM) julkaiseman selvityksen mukaan työnantajina toimivien järjestöjen määrä kaksinkertaistui 1990-luvulta 2010-luvulle. Vuonna 2011 kolmannella sektorilla tehtiin palkkatyönä viisi prosenttia kansantaloudessa tehdyistä henkilötyövuosista. (Ruuskanen ym. 2013, 10.)

Kolmannen sektorin kasvava rooli työllistäjänä liittyy väestön ikärakenteen muutokseen, 1990-luvulla toteutettuun julkisen palvelutuotannon rahoitusmallin uudistukseen sekä Suomen liittymiseen Euroopan Unioniin (Ruuskanen ym. 2013). Väestön ikärakenteen muutoksesta seurannut kasvava palveluiden tarve yhdessä julkisten palveluiden rahoitusmallin muutosten kanssa on ohjannut rahoitusta kolmannelle sektorille ja siten ammatillistanut sen toimintaa. Kunnat, valtio, Euroopan sosiaalirahasto ja RAY ovat merkittäviä kolmannen sektorin ammatillisen toiminnan rahoittajia. (Pihlaja 2010, 11-12; Ruuskanen ym. 2013, 19-24, 93-94.) Kolmannen sektorin rooli on uudistusten myötä kasvanut kulttuuri-, harrastus- sekä sosiaali- ja terveyspalveluiden tarjoajana julkisen ja yksityisen sektorin rinnalla (Pihlaja 2010, 34-35; Ruuskanen ym. 2013, 21-24).
Kolmannen sektorin työoloja ja työssä jaksamista ei ole toistaiseksi juurikaan tutkittu verrattuna esimerkiksi yksityisen ja julkisen sektorin työoloihin. Kolmas sektori ei työoloiltaan välttämättä suoraan vastaa julkista tai yksityistä sektoria, sillä sen rahoitus nojaa yksityistä ja julkista sektoria useammin projektiluonteisiin rahoituksiin, lahjoituksiin, tukiin ja jäsenmaksuihin. Kolmannen sektorin erityispiirteitä ovat juridinen yksityisyys, voittoa tavoittelemattomuus, itsehallinnollisuus, instituutionaalisuus ja vapaaehtoisuus (Saukkonen 2013). Kolmannen sektorin toiminta on kuitenkin saanut uusia muotoja, joissa kaikki edellä mainitut kriteerit eivät välttämättä tiukasti tarkasteltuna täyty (emt).

TEM:n selvityksessä (Ruuskanen ym. 2013) kävi ilmi, että kolmannen sektorin työntekijät kokevat muita sektoreita enemmän kiirettä, vähemmän mahdollisuuksia vaikuttaa työnsä sisältöön sekä enemmän ongelmia työn ja perheen yhteensovittamisessa. Työn jatkuvuutta koskeva epätietoisuus ja työn sisältöjen muutokset lisäävät epävarmuuden kokemuksia kolmannella sektorilla verrattuna julkiseen ja yksityiseen sektoriin, ja kolmannen sektorin työntekijät pohtivat muiden sektoreiden työntekijöitä useammin työpaikan vaihtamista. Selvityksessä vertailtiin kolmannelta sektorilta erillisotoksella kerättyjä tietoja Tilasto- 
keskuksen Työolotutkimus 2008 -aineistoon.

Kolmannen sektorin työntekijöiden työolojen kehittäminen on tärkeää sekä inhimillisistä syistä että lahjakkaiden työntekijöiden houkuttelemiseksi sektorille, joka tekee merkittävää työtä suomalaisten hyvinvoinnin edistämiseksi. Tilanteesta on saatavilla uutta tietoa, sillä Tilastokeskuksen uusimman, vuonna 2013 suoritetun haastattelukierroksen kyselylomaketta muokattiin Kuntoutussäätiön ja muun asiantuntijaryhmän toimesta siten, että se mahdollistaa kolmannella sektorilla työskentelevien työolojen tarkastelun sekä vertailun muilla sektoreilla työskenteleviin. Tätä uutta aineistoa hyödynnetään tässä katsauksessa. Katsaus tuo tärkeää uutta tietoa sekä Suomessa että kansainvälisesti vähän tutkitusta aiheesta. Tarkastelun tuloksia voidaan hyödyntää kolmannen sektorin työoloihin liittyvien haasteiden tunnistamisessa ja työolojen kehittämisessä.

Tavoitteena on selvittää, 1) eroavatko kolmannen sektorin työntekijöiden työolot, asennoituminen työhön ja kuntoutustarpeet muista sektoreista ja 2) miten kolmas sektori vertautuu yksittäisiin sektoreihin työolojen, työhön asennoitumisen ja kuntoutustarpeiden osalta.

\section{Aineisto ja menetelmät}

Tutkimus toteutettiin Tilastokeskuksen Työolotutkimuksen vuoden 2013 aineistolla, jossa on mukana kolmannen sektorin työntekijöiden tunnistamisen mahdollistava muuttuja. Työolotutkimus toteutetaan käyntihaastatteluin viiden vuoden välein osana Tilastokeskuksen työvoimatutkimusta (SVT 2013). Työolo-tutkimuksen kohdejoukko on 15-64-vuotiaat suomen- tai ruotsinkieliset palkansaajat, jotka työskentelevät vähintään 10 tuntia viikossa. Vuonna 2013 vastausprosentti oli naisilla 68,7 ja miehillä 67. Vastausaktiivisuus vaihteli eri ikäryhmissä 59-78 prosentin välillä. (Emt.)

Vuonna 2013 Työolotutkimukseen osallistui yhteensä 4876 henkilöä. Tässä tarkastelussa ovat mukana 20-64-vuotiaat vastaajat, 4815 henkilöä. Kolmannen sektorin työnte- kijöitä oli tarkastelussa mukana 137 eli 2,9 prosenttia kaikista vastanneista. Kolmanteen sektoriin kuuluvien osuus oli hieman pienempi kuin kolmannella sektorilla tehtävien henkilötyövuosien osuus (5 prosenttia) kaikista tehdyistä henkilötyövuosista vuonna 2011 (Ruuskanen ym. 2013, 10). Kolmatta sektoria ei ole erikseen rekisteröity Tilastokeskuksen ylläpitämään yritysrekisteriin, mutta Työolotutkimuksen vuoden 2013 kyselylomakkeeseen oli lisätty kysymykseen "Onko nykyinen työnantajanne" vaihtoehdoksi "kolmas sektori”, jonka lomakkeessa tarkennettiin viittaavan esimerkiksi yhdistykseen, säätiöön, uusosuuskuntaan tai sosiaaliseen yritykseen (SVT 2013). Tilastokeskuksen yritysrekisteriin ja aineiston vastauksiin perustuvan muuttujan avulla voitiin erotella työnantajiksi ns. "budjettivaltio" ( $\mathrm{N}=255)$, kunta $(\mathrm{N}=1328)$, yliopisto tai korkeakoulu ( $\mathrm{N}=108)$, yksityinen sektori $(\mathrm{N}=2987)$ ja kolmas sektori $(\mathrm{N}=137)$.

Tarkastelussa verrattiin kolmannen sektorin työntekijöiden motivaatiota, työoloja ja kuntoutustarpeita muihin sektoreihin sekä yhdessä että erikseen.

Työoloja ja motivaatiota mitattiin Työterveyslaitoksella kehitetyn työkykytalon luokittelujen pohjalta (Ilmarinen ym. 2006, 2225). Työkykytalo kuvastaa työkykyyn vaikuttavia tekijöitä neljän kerroksen avulla. Tässä tutkimuksessa hyödynnettiin kolmanteen ja neljänteen kerrokseen luokiteltavia tekijöitä. Kolmas kerros kuvastaa yksilön asenteita ja työhön liittyvää arvomaailmaa sekä työhön motivoivia tekijöitä. Neljäs kerros taas ilmentää varsinaista työyhteisöä, johtamista ja työoloja. (Emt.)

Työhön ja työoloihin liittyvistä tekijöistä kartoitettiin työsuhteen laatua, etenemismahdollisuuksia, työssä koettua autonomiaa ja työtehtävien vaihtelevuutta. Työssä koettua autonomiaa tarkasteltiin summamuuttujalla, jossa oli huomioitu vaikutusmahdollisuudet työtehtäviin, työn tekemisen järjestykseen, työtahtiin, työmenetelmiin, työnjakoon, työtovereihin, aikautuluihin, työaikoihin ja työmäärään (Crohnbachin alfa $=0,84)$. Johtamiseen ja työyhteisöön liittyvistä tekijöistä tarkasteltiin työpaikkakiusaamisen yleisyyttä 
ja työn organisointia. Työhön liittyvää motivaatiota mitattiin oman työn merkittävyyttä ja työn sisällön ja palkan välistä suhdetta kartoittavien muuttujien avulla. Lopuksi tarkasteltiin vielä kuntoutustarvetta, kuntoutukseen osallistumista ja tyydyttämätöntä kuntoutustarvetta kolmannella ja muilla sektoreilla. Tyydyttämätön kuntoutustarve viittaa tässä tilanteeseen, jossa henkilö kokee tarvitsevansa kuntoutusta, mutta ei ole osallistunut kuntoutukseen viimeisten 12 kuukauden aikana.

Menetelminä käytettiin ristiintaulukointia, 95 prosentin luottamusvälejä ja -testiä. Tarkasteluja ei tehty sukupuolille erikseen aineiston voiman säilyttämiseksi. Kolmannella sektorilla työskentelevistä 137 vastaajasta miehiä oli ainoastaan 46. Osuudet on ikävakioitu, vakioväestönä on käytetty vuoden 2013 työllisiä (SVT 2016).

\section{Yksityistä sektoria enemmän määräaikaisia työsuhteita, keskimääräiset etenemismahdollisuudet ja yllättävän paljon työpaikkakiusaamista}

Kolmannella sektorilla työskentelevistä vastaajista naisia oli 66 prosenttia, joka oli selvästi enemmän kuin muilla sektoreilla, joilla naisia oli hieman yli puolet vastaajista. Kolmannen sektorin vastaajien keski-ikä oli 46 vuotta, mikä oli korkeampi kuin muiden sektoreiden työntekijöiden keski-ikä, 44 vuotta. Kolmannella sektorilla työskentelevistä kolme viidestä työskenteli alle 20 henkilön toimipaikassa, kun muilla sektoreilla alle 20 henkilön toimipaikoissa työskenteleviä oli kaksi viidestä.

Kolmannella sektorilla viidennes työskenteli määräaikaisessa työsuhteessa, kun muilla sektoreilla määräaikainen työsopimus oli 13 prosentilla. Määräaikaisten työsuhteiden yleisyydessä oli selkeitä eroja eri sektoreiden välillä (kuvio 1). Yleisimpiä ne olivat yliopistoissa ja korkeakouluissa (46 \%) ja kunnissa (25\%), mutta ainoastaan erot yliopistojen ja kolmannen sektorin työntekijöiden sekä yksityisen ja kolmannen sektorin välillä olivat tilastollisesti merkitseviä. Osuus oli pienin yksityisellä sektorilla, jolla vain seitsemän prosenttia oli mää- räaikaisessa työsuhteessa. (Kuvio 1.)

Kolmannella sektorilla reilu puolet, yhtä moni kuin muilla sektoreilla, koki etenemismahdollisuutensa heikoiksi. Etenemismahdollisuuksien suhteen vaihtelu oli kuitenkin suurehkoa sektoreiden välillä. Etenemismahdollisuutensa heikoiksi kokevien osuus oli pienin yliopistoissa tai korkeakouluissa työskentelevillä (42\%) ja suurin kuntasektorilla työskentelevillä (63 \%). Sen sijaan kolmas sektori ei eronnut tilastollisesti merkitsevästi mistään yksittäisestä sektorista.

Työpaikkakiusaamista mitattiin kysymyksellä, jossa vastaajaa pyydettiin määrittelemään, esiintyikö hänen työpaikallaan työpaikkakiusaamista jatkuvasti, joskus vai ei ollenkaan. Kolmannella sektorilla jatkuvaa kiusaamista esiintyi keskimääräistä enemmän. Jopa 13 prosenttia raportoi jatkuvasta kiusaamisesta, kun muilla sektoreilla osuus oli 6 prosenttia. Kolmas sektori erosi jatkuvan kiusaamisen yleisyydessä tilastollisesti merkitsevästi vain yksityisestä sektorista. Kolmannen sektorin työntekijöiden vastaukset painottuivat muita sektoreita vahvemmin kiusaamisen ääripäihin, eli joko sitä ei esiintynyt ollenkaan tai se oli jatkuvaa. Kolmannella sektorilla työskentelevissä oli kunnassa työskenteleviin verrattaessa enemmän niitä, jotka eivät kokeneet työpaikallaan ollenkaan kiusaamista.

\section{Vaihtelevaa ja autonomista työtä}

Työnsä erittäin vaihtelevaksi kokeminen oli kolmannella sektorilla muita sektoreita yleisempää. Peräti 46 prosenttia koki työtehtävänsä erittäin vaihteleviksi, kun muilla sektoreilla työskentelevistä keskimäärin kolmannes koki työnsä erittäin vaihtelevaksi. Sektorikohtaisessa vertailussa kolmannen sektorin työnsä vaihtelevaksi kokevien osuus oli edelleen korkein, ja sitä lähimmiksi ylsivät kunnat, joissa työskentelevistä 41 prosenttia koki työnsä erittäin vaihtelevaksi (kuvio 2). Työnsä erittäin vaihtelevaksi koki kolmannella sektorilla useampi kuin yksityisellä sektorilla. Sen sijaan kolmannen sektorin, julkisen sektorin sekä yliopistojen ja korkeakoulujen välillä ei ollut tilastollisesti merkitsevää eroa. Kolman- 


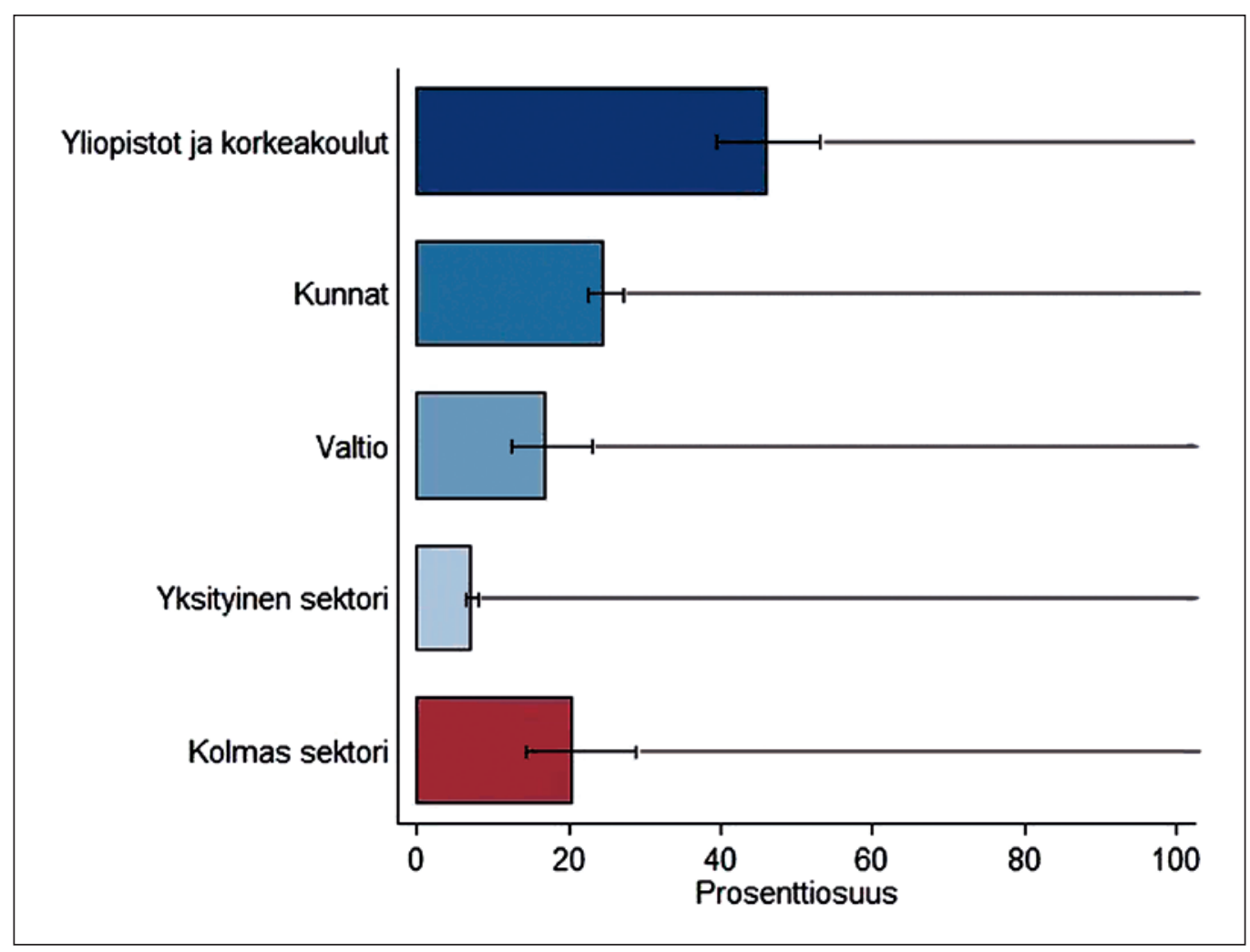

Kuvio 1. Työntekijöiden työsuhteen määräaikaisuus, osuudet (\%) sektoreittain ja 95 \%:n luottamusvälit, ikävakioitu.

nella sektorilla työskentelevien joukossa oli hieman enemmän myös niitä, jotka kokivat työnsä melko yksitoikkoiseksi (kuvio 2).

Kolmannen sektorin työntekijöiden työssään kokema autonomia poikkesi selkeästi muiden sektoreiden työntekijöiden autonomiasta. Kolmannen sektorin työntekijöistä jopa 39 prosentilla oli korkea autonomia työssään, kun muiden sektoreiden työntekijöistä näin oli joka neljännellä. Työssään korkeaa autonomiaa kokevien osuus oli kolmannella sektorilla merkittävästi korkeampi kuin julkisella ja yksityisellä sektorilla. Sen sijaan vielä korkeampaa autonomiaa koettiin yliopistoilla ja korkeakouluissa, joissa korkeasta autonomiasta nautti 41 prosenttia työntekijöistä.

Kolmannen sektorin työntekijöistä neljä viidestä oli jokseenkin samaa tai täysin samaa mieltä siitä, että heidän työpaikallaan työt on organisoitu hyvin. Eroa muihin sektoreihin ei löytynyt. Myöskään yksittäisten sektoreiden välillä ei ollut eroa tyytyväisyydessä töiden organisoimiseen.

\section{Merkittäväksi koettua työtä, jossa työn sisältö on palkkaa tärkeämpi}

Kolmannella sektorilla työ koettiin merkittäväksi ja työn sisältöä arvostettiin palkkaa enemmän. 41 prosenttia kolmannen sektorin työntekijöistä koki työnsä erittäin merkittäväksi, mikä vastasi suunnilleen muiden sektorien keskiarvoa. Lisäksi vähemmän kuin 7 prosenttia oli sellaisia, jotka eivät kokeneet työtään erityisen tai lainkaan merkittäväksi, mikä vastasi muiden sektoreiden lukuja.

Kun kokemusta työn merkittävyydestä tarkasteltiin sektorikohtaisesti, ilmeni selkeitä eroja sektoreiden välillä. Kunnalla työskentelevistä jopa 55 prosenttia koki työnsä erittäin 


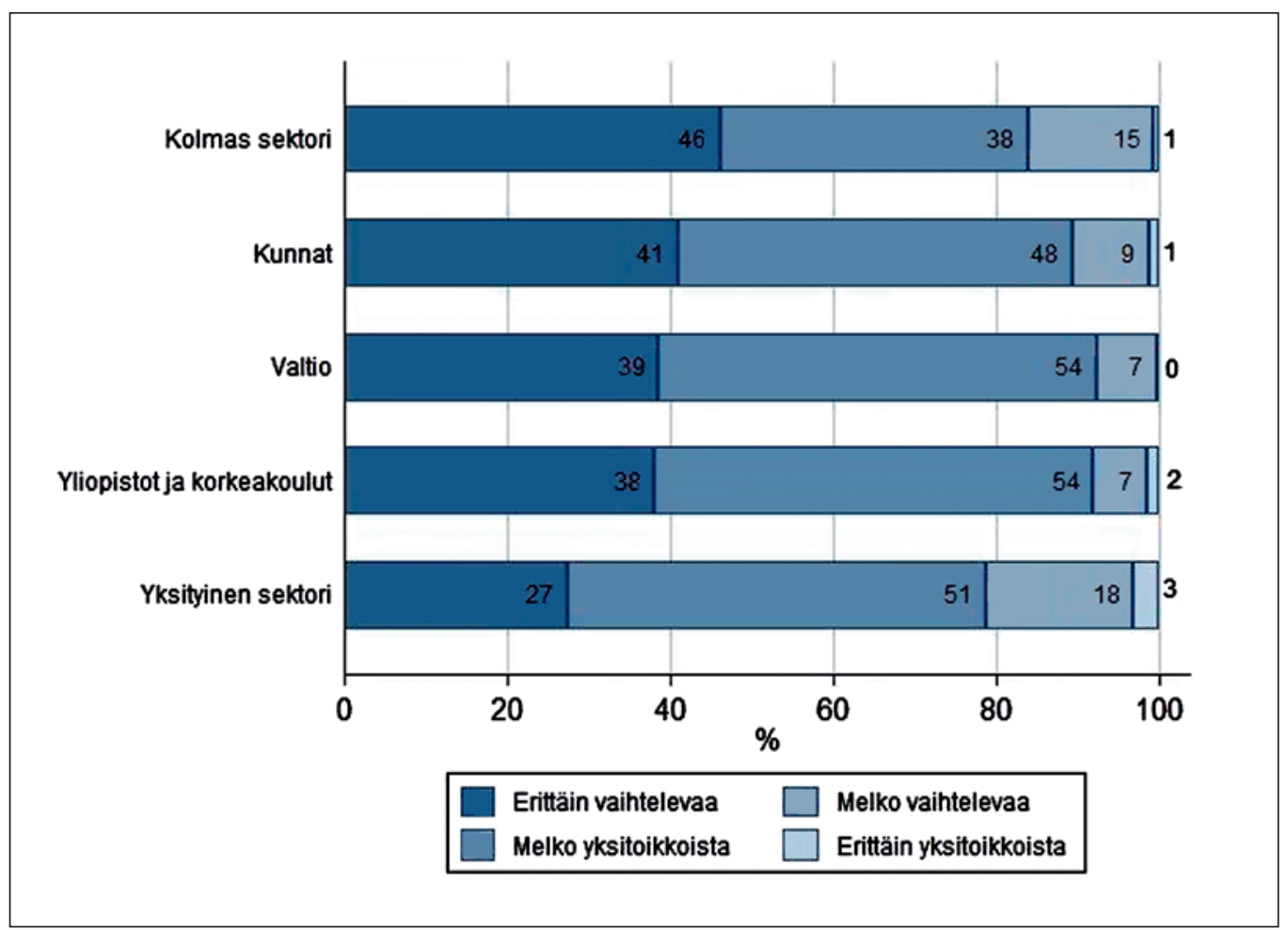

Kuvio 2. Työn vaihtelevuus, osuudet (\%) sektoreittain, ikävakioitu.

merkittäväksi ja vain 2 prosenttia piti työtään vain vähän tai ei lainkaan merkittävänä. Ero kolmanteen sektoriin oli tilastollisesti merkitsevä. Sen sijaan valtiolla, yliopistoilla ja yksityisellä sektorilla työskentelevistä vain vajaa kolmannes koki työnsä erittäin merkittäväksi. Ainoastaan yksityisellä ja kolmannella sektorilla työskentelevien välillä oli tilastollisesti merkitsevä ero.

Kolmannella sektorilla työskentelevät pitivät työn sisältöä palkkaa tärkeämpänä selvästi yleisemmin kuin muilla sektoreilla työskentelevät. Lähes neljä viidestä kolmannella sektorilla työskentelevästä piti työn sisältöä jossain määrin tai ehdottomasti palkkaa tärkeämpänä, kun muilla sektoreilla vastaava osuus oli kolme viidestä. Ero muihin sektoreihin oli tilastollisesti erittäin merkitsevä.

Sektoreiden välillä oli selkeitä eroja myös siinä, miten tärkeäksi palkka koettiin suhteessa työn sisältöön (kuvio 3). Työn sisältöä painottivat eniten yliopistolla tai korkeakou- lussa työskentelevät, joista melkein yhdeksän kymmenestä koki työn sisällön palkkaa tärkeämmäksi. Seuraavaksi suurin osuus oli kolmannella sektorilla ja julkisella sektorilla työskentelevillä. Kolmannen sektorin ero julkisella sektorilla tai yliopistoissa ja korkeakouluissa työskenteleviin ei kuitenkaan ollut tilastollisesti merkitsevä. Yksityinen sektori erottui selkeästi muista sektoreista palkkaa enemmän painottavien suuremmalla osuudella. Yksityisellä sektorilla työskentelevistä 57 prosenttia piti työn sisältöä palkkaa merkittävämpänä, kun kaikilla muilla sektoreilla vastaava osuus oli yli 70 prosenttia.

\section{Kuntoutustarve samansuuntainen kaikilla sektoreilla}

Kuntoutustarpeen ja kuntoutukseen osallistumisen osalta kolmannen sektorin vastaajat eivät erottuneet muista vastaajista (kuvio 4). Kolmannella sektorilla vajaa viidennes koki 


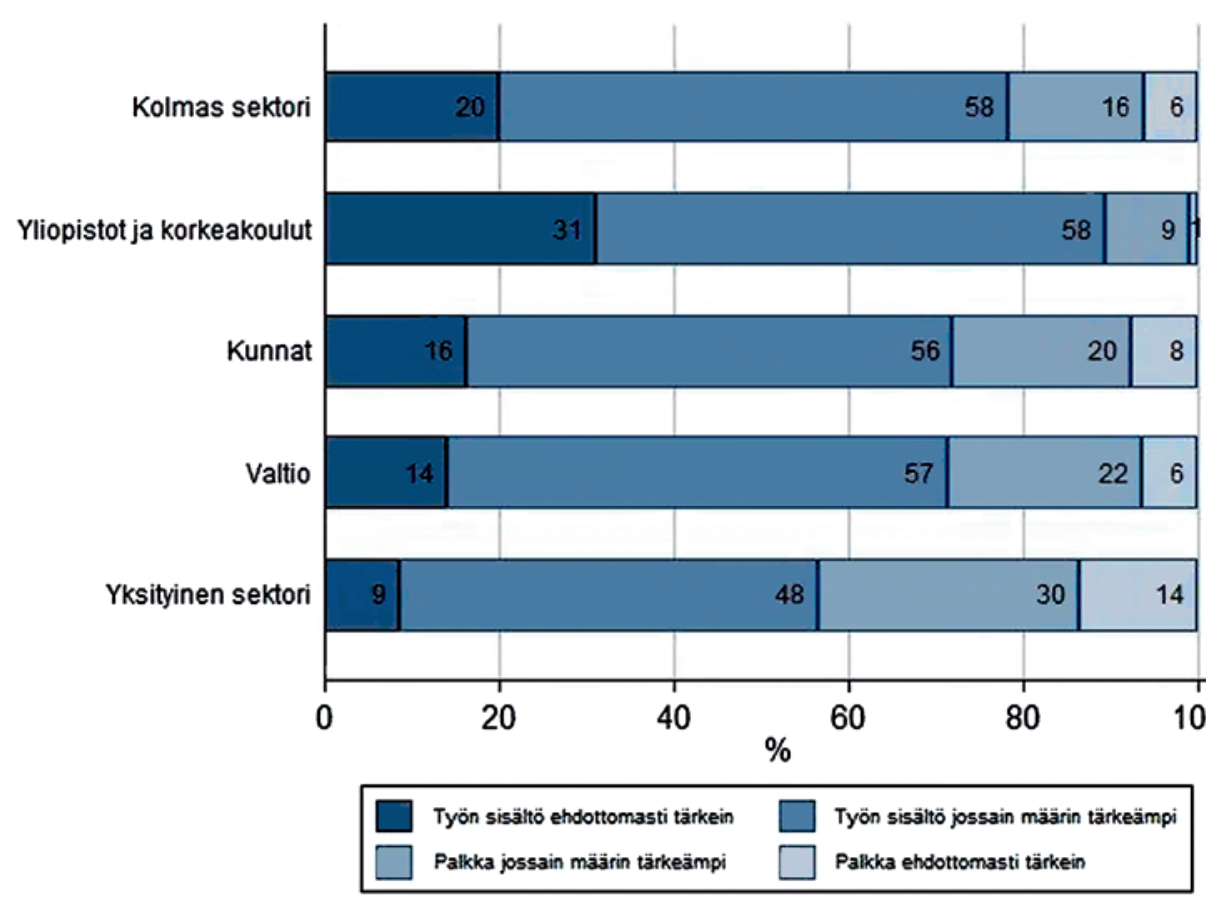

Kuvio 3. Vastaajien mielipidettä työstä parhaiten kuvaava vaihtoehto (palkka vai työnsisältö tärkein/ tärkeämpi), osuudet (\%) sektoreittain, ikävakioitu.

tarvitsevansa työ- ja toimintakykyä parantavaa kuntoutusta, ja noin viisi prosenttia oli osallistunut kuntoutukseen viimeisten 12 kuukauden aikana. Suhteessa eniten kuntoutusta tarvitsivat kunnalla työskentelevät, 23 prosenttia, ja vähiten yliopistolla tai korkeakoulussa työskentelevät, joista noin 16 prosenttia arvioi tarvitsevansa kuntoutusta.

Tyydyttämätöntä kuntoutustarvetta tarkasteltiin niiden osuutena, jotka kokivat tarvitsevansa kuntoutusta mutta eivät kuitenkaan olleet osallistuneet kuntoutukseen viimeisten 12 kuukauden aikana. Tyydyttämätöntä kuntoutustarvetta kokevien osuus oli kolmannella sektorilla noin 16 prosenttia, joka oli sama kuin muilla sektoreilla työskentelevillä keskimäärin (kuvio 4). Sektorien välillä oli kuitenkin eroja. Harvinaisinta tyydyttämätön tarve oli yliopistoissa tai korkeakouluissa työskentelevien joukossa, josta joka kymmenes koki tarvitsevansa kuntoutusta mutta ei ollut osallistunut kuntoutukseen. Yleisintä tyydyttämätön tarve oli kuntasektorilla, jolla viidennes koki tyydyttämätöntä kuntoutustarvetta.

\section{Johtopäätökset: Autonomiaa, sisäistä motivaatiota ja vaihtelevaa työtä määräaikaisissa työsuhteissa}

Kolmannen sektorin työntekijöillä oli muilla sektoreilla työskenteleviä yleisemmin autonominen ja vaihteleva työ. He myös korostivat muita useammin työn sisältöä palkkaa tärkeämpänä tekijänä. Toisaalta määräaikaiset työsuhteet olivat kolmannella sektorilla yksityistä sektoria yleisempiä. Kolmannen sektorin työntekijöiden kuntoutustarve ei poikennut muista sektoreista. Jatkuvaa kiusaamista esiintyi kolmannella sektorilla hieman useammin kuin muilla sektoreilla.

Sektorikohtaisessa tarkastelussa ilmeni, että kolmannen sektorin työolot ja työtä kohtaan koetut asenteet olivat usein lähellä jul- 


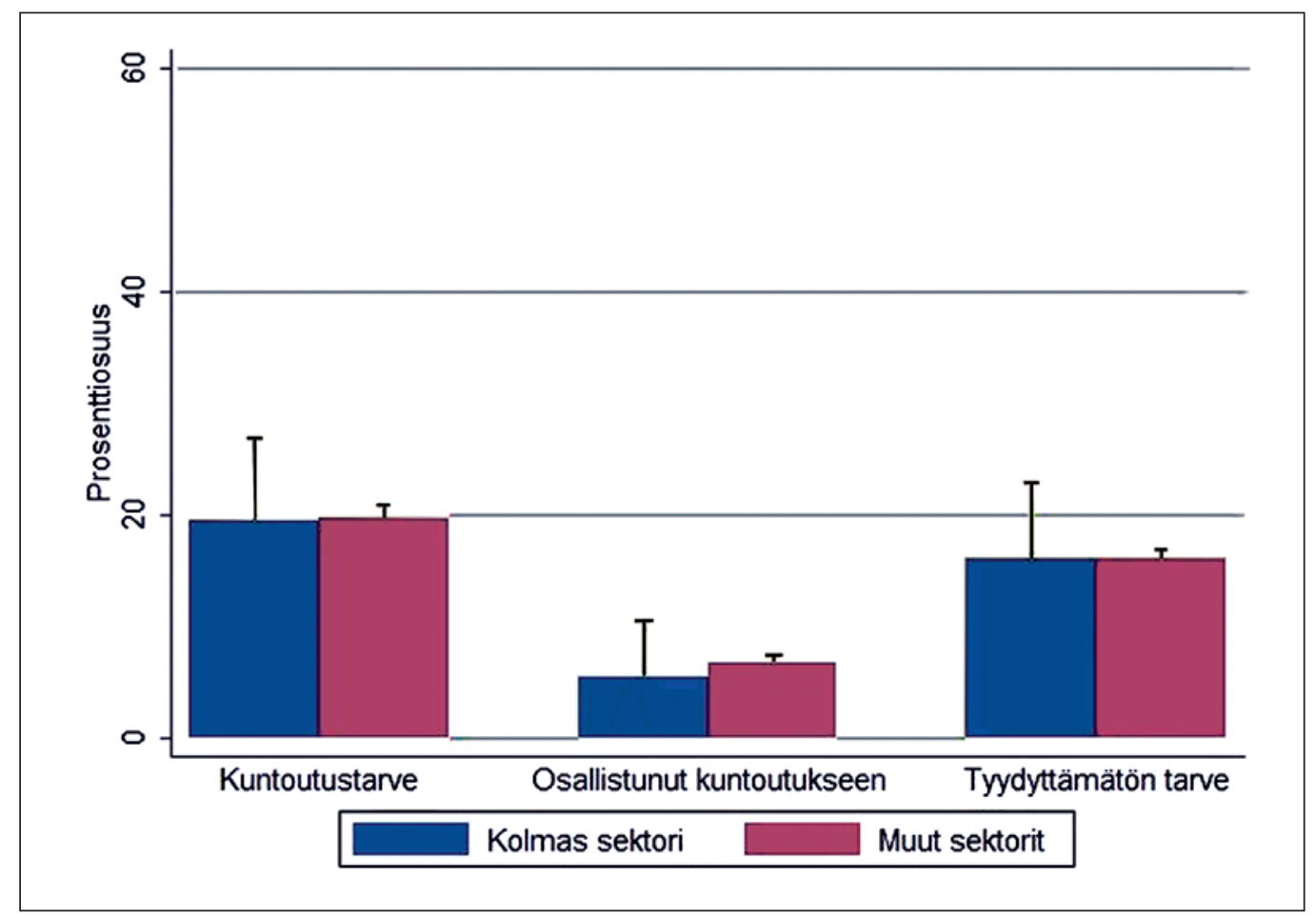

Kuvio 4. Itse arvioitu kuntoutuksen tarve, viim. 12 kk:n aikana kuntoutukseen osallistuneet ja tyydyttämätön kuntoutustarve, osuudet (\%) kolmas sektori ja muut sektorit, 95 \%:n luottamusvälit, ikävakioitu.

kisella sektorilla työskentelevien ja useimmiten myös yliopistoilla tai korkeakouluissa työskentelevien työoloja ja asenteita. Sen sijaan yksityisen sektorin työolot ja työtä kohtaan koetut asenteet poikkesivat usein kaikista edellä mainituista sektoreista.

Kolmannen sektorin työntekijöitä yhdistää korkea autonomia ja työtä kohtaan tunnettu sisäinen motivaatio. Kummatkin tulokset ovat yhteneviä TEM:n selvityksen kanssa (Ruuskanen ym. 2013, 46, 59-60). Autonomia työssä oli kolmannella sektorilla suurta, ja ainoastaan yliopistolla ja korkeakouluissa nautittiin kolmatta sektoria useammin suurta autonomiaa. TEM:n selvityksessä kolmannella sektorilla koettu suuri autonomia liittyi työtehtävien sisältöön ja menetelmiin sekä työaikoihin, kun taas oman osaamisen soveltaminen oli kolmannella sektorilla heikompaa kuin yksityisellä sektorilla (Ruuskanen ym. 2013, 59-60). Tässä tarkastelussa autonomian ulottuvuuksia ei eroteltu.
Sisäinen motivaatio oli sekä TEM:n selvityksessä että tässä tarkastelussa yleistä kolmannen sektorin työntekijöillä. Jopa neljä viidestä tässä tarkastelussa ja kolme neljästä TEM:n selvityksessä piti työn sisältöä palkkaa tärkeämpänä (Ruuskanen ym. 2013). Työn sisältöä palkkaa enemmän arvostettiin tässä tarkastelussa kolmatta sektoria useammin vain yliopistoissa ja korkeakouluissa. Lisäksi omaa työtään ei erityisen merkittäväksi tai ei lainkaan merkittäväksi kokevien osuus oli kolmatta sektoria (6 \%) pienempi ainoastaan kunnissa (2\%).

Kolmas sektori ei eronnut kuntoutustarpeeltaan, kuntoutukseen osallistumiseltaan tai tyydyttämättömältä kuntoutustarpeeltaan muista sektoreista tilastollisesti merkitsevästi. Vaikka tässä tarkastelussa ei eroja kuntoutustarpeessa tai kuntoutukseen osallistumisessa löytynyt, kolmannen sektorin työntekijöiden koettua kuntoutustarvetta olisi hyvä kartoittaa jatkossakin. Lisäksi hieman huolestuttava 
havainto oli jatkuvaa kiusaamista kokeneiden yleisyys kolmannella sektorilla. Myös TEM:n selvityksessä ilmeni, että kolmannen sektorin työntekijät olivat julkiseen ja yksityiseen sektoriin verrattuina tyytymättömämpiä työilmapiiriin (Ruuskanen ym. 2013, 54).

Kolmas sektori on käsitteenä vaikeasti määriteltävä, ja se sisältää hyvin monimuotoista toimintaa, mikä hankaloittaa työoloihin liittyvää tutkimusta. Kolmannella sektorilla työtä tehdään hyvin erilaisissa organisaatioissa julkisen sektorin palveluntuotantoa vastaavista yhdistyksistä lähes vapaaehtoisvoimin toimiviin paikallisyhdistyksiin (ks. esim. Pihlaja 2013, 92-93). Kolmannen sektorin työntekijöiden vastausten painottuminen vastausvaihtoehtojen äärilaidoille kielii kolmannella sektorilla tehdyn työn monimuotoisuudesta. Tarkastelun analyyseissa sukupuolia ei eroteltu, mikä on osittain saattanut vaikuttaa tuloksiin. Erityisesti yksityisellä sektorilla miehiä oli selvästi enemmän suhteessa muihin sektoreihin. Jatkotutkimuksissa hyödyllistä olisi tarkastella naisten ja miesten erojen lisäksi työpaikan koon yhteyttä kolmannen sektorin työoloihin ja työtä kohtaan koettuihin asenteisiin eri sektoreilla. Esimerkiksi töiden vaihtelevuus voi osittain johtua siitä, että kolmannella sektorilla työskennelleiden työpaikat olivat kooltaan keskimäärin pienempiä (vrt. Ruuskanen ym. 2013). Kiinnostavaa olisikin selvittää, mitkä tekijät selittävät kolmannen sektorin eroa muihin sektoreihin erityisesti sisäisessä motivaatiossa ja suuressa autonomiassa. Myös työyhteisöön liittyvien tekijöiden, kuten jatkuvan kiusaamisen, yhteyttä koettuun kuntoutustarpeeseen voisi olla hyödyllistä tarkastella lisää.

Maari Parkkinen, VTM, tutkija, Kuntoutussäätiö

Riikka Shemeikka, VTT, johtaja, tutkimus, Kuntoutussäätiö

Aurora Saares, VTM, tutkija, Kuntoutussäätiö

Hanna Rinne, VTM, tutkija, Kuntoutussäätiö

\section{Lähteet}

Ilmarinen J, Gould R, Järvikoski A, J Järvisalo (2006) Työkyvyn moninaisuus. Teoksessa R Gould, J Ilmarinen, J Järvisalo, S Koskinen (toim.) (2006) Työkyvyn ulottuvuudet. Terveys 2000 -tutkimuksen tuloksia. Eläketurvakeskus, Kansaneläkelaitos, Kansanterveyslaitos, Työterveyslaitos. Hakapaino Oy, Helsinki, 17-34.

Pihlaja R (2012) Kolmas sektori ja julkinen valta. Kunnallisalan kehittämissäätiön tutkimusjulkaisut, nro 61. Verkkojulkaisu, viitattu 3.2.2016. Saantitapa: http://www.kaks.fi/sites/default/files/Tutkimusjulkaisu\%2061.pdf

Ruuskanen P, Selander K, T Anttila (2013) Palkkatyössä kolmannella sektorilla. Työ- ja elinkeinoministeriön julkaisuja Työ ja yritteliäisyys 20 . Verkkojulkaisu, viitattu: 25.1.2016. Saantitapa: https://www.tem.fi/files/37094/TEMjul_20_2013_ web_27062013.pdf

Saukkonen P (2013) Kolmas sektori - Vanha ja uusi. Kansalaisyhteiskunta 1, 6-31.

SVT (Suomen virallinen tilasto) (2012) Väestöennuste. Liitetaulukko 1, Väestö ikäryhmittäin koko maa 1900-2060 (vuodet 2020-2060: ennuste). Tilastokeskus, Helsinki. Verkkojulkaisu, viitattu 27.1.2016 Saantitapa: http://www.stat.fi/til/vaenn/2012/vaenn_2012_2012-09-28_tau_001_fi.html

SVT (Suomen virallinen tilasto) (2013) Työolotutkimus 2013, Laatuseloste. Tilastokeskus, Helsinki. Verkkojulkaisu, viitattu: 25.1.2016. Saantitapa: http:// www.stat.fi/til/tyoolot/laa.html

SVT (Suomen virallinen tilasto) (2016) Väestö pääasiallisen toiminnan, sukupuolen, iän (1-v) ja vuoden mukaan 1987-2014. Työlliset/Väestö. Osataulukko. Tilastokeskus. Viitattu: 8.2.2016. Saantitapa: StatFin-tietokanta. 